\title{
Lymphoma in the Japanese medaka Oryzias latipes
}

\author{
M. S. Okihiro' ${ }^{\text {, D. E. Hinton }}{ }^{2}$ \\ ${ }^{1}$ Department of Pathology, School of Veterinary Medicine, University of California-Davis, Davis, California 95616, USA \\ ${ }^{2}$ Department of Medicine, School of Veterinary Medicine, University of California-Davis, Davis, California 95616, USA
}

\begin{abstract}
Six adult Japanese medaka Oryzias latipes were diagnosed with lymphoma, over a 6 mo period, from a control population of broodstock fish. Tumors were equally split among males and females, and presented as either grossly visible cranial masses, unilateral exophthalmos, or with no gross lesions. Tumors were classified as renal, thymic, or disseminated based on histologic distribution and the extent of neoplastic infiltrate. Metastatic lesions were found in all 6 fish and occurred via both direct extension and vascular invasion. The etiology of the tumors has not been determined.
\end{abstract}

\section{INTRODUCTION}

The Japanese medaka Oryzia latipes is a small, easily maintained, fresh-water aquarium fish that is increasingly used as subjects for carcinogenesis studies because of its sensitivity to xenobiotic compounds, short latency period to liver tumor development, and high tumor yield (Hinton et al. 1985). One of the problems in dealing with a relatively new laboratory animal, such as the medaka, is that the background incidence of naturally occurring tumors is unknown and that information is critical for proper interpretation of data from xenobiotic exposures. We are currently using the Japanese medaka as test subjects for carcinogenesis studies at the University of California, Davis, USA, and have begun screening all dead or moribund fish in our rearing facility for background tumors. The most common tumor found thus far in our control broodstock population is the lymphoma.

Lymphomas are malignant neoplasms of lymphoid tissue and are one of the most common tumors of domestic mammals (Moulton \& Dungworth 1978). Lymphomas are less common in poikilotherms (Dawe 1969. Harshbarger \& Dawe 1973), but have been reported in several species of teleost fish. Various reviews of neoplasia in fish (Schlumberger \& Lucke 1948, Wellings 1949, Mawdesley-Thomas 1975) have revealed lymphoma in up to 16 different fish species. Among bony fishes, the most commonly affected species were those belonging to the order Salmoniformes. Large epizootics of cutaneous lymphomas have been reported in north- ern pike Esox lucius from Sweden (Ljungberg 1976), Ireland (Mulcahy 1963, 1976), Finland (Thompson 1982), and North America (Sonstegard 1976). Sonstegard $(1975,1976)$ also reported similar epizootics of cutaneous lymphomas in muskellunge Esox masquinongy from Canada. In contrast to the epizootics in esocid species, reports of lymphoma in trout and salmon have been isolated cases in individual fish. Trout and salmon species reported with lymphoma include the rainbow trout Oncorhynchus mykiss (Herman 1969, Harshberger 1980, Bernstein 1984, Warr et al. 1984), cuthroat trout Salmo clarki (Smith 1971), brook trout Salvelinus fontinalis (Dunbar 1969), and Atlantic salmon Salmo salar (Haddow \& Blake 1933, Roald \& Hastein 1979). This report details on 6 cases of lymphoma in the Japanese medaka Orizias latipes.

\section{MATERIALS AND METHODS}

All fish collected for this study were housed in plexiglass aquaria as part of a partially recirculating freshwater system and were either dead, moribund, or had a grossly visible lesion when removed from the colony. Live and moribund fish were killed with an overdose of methane sulfonate salt (MS-222). Fish were fixed whole in either Bouin's or half-strength Karnovsky's solution for at least $24 \mathrm{~h}$. Fixed fish, without external tumors, were longitudinally bisected prior to processing, while fish with external masses were transversely cross-sectioned behind the gill opercula in addition to 
having the posterior two-thirds of the fish longitudinally bisected. All tissues were dehydrated through a series of graded alcohols, embedded in paraffin or glycol methacrylate, sectioned at $5 \mu \mathrm{m}$, and stained with hematoxylin and eosin ( $H \& E$ ). All blocks were step sectioned sequentially until sections of all internal organs were obtained. The degree of tumor infiltrate was determined subjectively and graded on a scale of 1 to $4+$ (with $4+$ being the most severe). Parts of tumors from 2 fish (Fish 4 and 6 ) were also embedded in epoxy resin, cut with a diamond knife at 800 to $900 \AA_{\text {, stained }}$ with $2 \%$ uranyl acetate and Reynolds' lead citrate, and examined via transmission electron microscopy (TEM).

\section{RESULTS}

\section{Gross necropsy findings}

Six adult medaka, from a total of 3000 , were diagnosed with lymphoma over a 6 mo period from October 1988 to March 1989. All tumor bearing fish were sexually mature (estimated age 1 to $2 \mathrm{yr}$ ) and ranged in total length from 3.2 to $4.4 \mathrm{~cm}$ (Table 1). Three were females and 3 males. Four fish (Fish 3 to 6 ) had grossly visible masses protruding from either the dorsal or lateral aspect of the head. Tumors found on the lateral aspect of the head were centered over the superior edge of the gill operculum and often extended from a point just caudal to the eye, to the base of the pectoral fin (Fig. 1). The tumors measured 4 to $6 \mathrm{~mm}$ diam. and were raised, pale yellow-white, and soft to gelatinous in texture. Tumors had ill-defined borclers and extended into the adjacent musculoskeletal structures of the head and body. Fish 1, which lacked a grossly visible tumor, had a markedly swollen left eye with an opaque cornea and Fish 2 had no gross lesions.

\section{Light microscopic findings}

The tumors in all 4 fish with grossly visible masses were unencapsulated and composed of monomorphic populations of small round cells arranged into densely packed, diffuse sheets with little intervening stroma (Fig. 2). The round cells had distinct cell borders, scant basophilic cytoplasm, and round, hyperchromatic nuclei. Cells ranged in size from 4 to $6 \mu \mathrm{m}$ diam., and the mitotic index was 0 to 4 mitotic units/high power field (HPF $=40 \times$ objective) (Table 2 ). The majority of tumors contained scattered, individually necrotic tumor cells along with moderate numbers of large macrophages that were packed with either coarsely granular debris or phagocytized tumor cells.

Grossly visible tumors were unilaterally centered in 1 of the 2 thymus glands. The neoplastic tissue com-
Table 1. Oryzias latipes. Gross necropsy findings in 6 medaka diagnosed with lymphoma. TL: total length $(\mathrm{cm})$

\begin{tabular}{|c|c|c|c|}
\hline Fish & Sex & TL & Gross lesions \\
\hline 1 & M & 4.2 & $\begin{array}{l}\text { Left eye markedly swollen with } \\
\text { opaque cornea }\end{array}$ \\
\hline 2 & $\mathrm{~F}$ & 3.5 & No gross lesions \\
\hline 3 & $\mathrm{~F}$ & 4.4 & $\begin{array}{l}6 \mathrm{~mm} \text { diam., raised mass protruding } \\
\text { from right side of head, dorsal to } \\
\text { operculum }\end{array}$ \\
\hline 4 & M & 3.5 & $\begin{array}{l}6 \mathrm{~mm} \text { diam., raised mass protruding } \\
\text { from left side of head, dorsal to oper- } \\
\text { culum }\end{array}$ \\
\hline 5 & $\mathrm{~F}$ & 3.2 & $\begin{array}{l}4.5 \mathrm{~mm} \text { diam, raised mass protruding } \\
\text { from dorsal aspect of head }\end{array}$ \\
\hline 6 & $M$ & 4.0 & $\begin{array}{l}5 \mathrm{~mm} \text { diam., raised mass protruding } \\
\text { from left side of head, dorsal to } \\
\text { operculum }\end{array}$ \\
\hline
\end{tabular}

pletely obliterated the normal architecture of the gland and both expanded outwards through the skin and inwards into the opercular cavity (Fig. 2). Tumors were highly invasive and infiltrated many adjacent structures of the head, including the oral submucosa, thyroid gland, skeletal muscle, inner ear, eye, gill, pericardial sac, and central nervous system (CNS) (Table 2). Components of the CNS most frequently involved were the cranial nerves and primitive meninx of the brain. In some fish, neoplastic tissue also extended into the superficial parenchyma of the brain and meninx of the spinal cord. The heart and peritoneal cavity were also infiltrated to various degrees in all 4 fish. In the heart, neoplastic foci were subendocardial with variable extension into the myocardium. In the peritoneal cavity, tumor foci were randomly scattered throughout the abdominal fat and exocrine pancreas. Other abdominal organs affected were kidney, liver, intestine, gonad, and spleen. The head kidneys of all 4 fish were severely infiltrated with massive replacement of the normal. interstitial hematopoietic tissue by monomorphic tumor cells (Fig. 3). There was wide separation of tubules and glomeruli by neoplastic tissue and marked enlargement of the entire organ. Interstitial blood vessels were often packed with tumor cells and the perirenal fat diffusely infiltrated. The liver, in 3 of 4 fish, contained multifocal, small, perivascular aggregates of tumor cells and tumor emboli could occasionally be found within hepatic blood vessels. The 2 female fish (Fish 3 and 5) with gross lesions, also had mild tumor infiltrates in the lamina propria of the intestine and multifocal, heavy infiltrates in the ovary (Fig. 3) and spleen. Tumors in all 4 fish with gross lesions were classified as disseminated lymphomas (Table 3 ) based on the involvement of multiple lymphoid organs and the widespread metastasis of the tumors. 

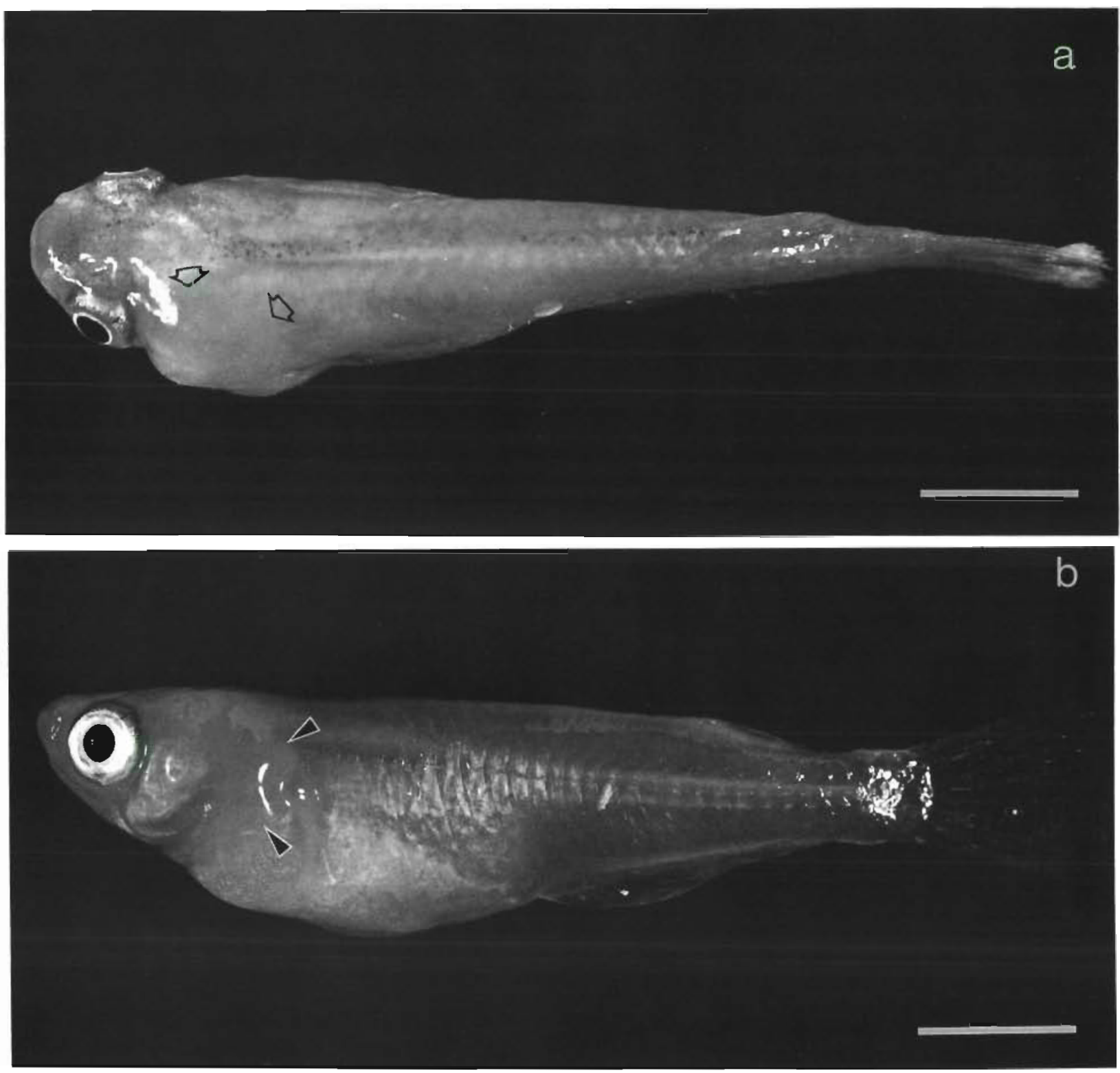

Fig. 1. Oryzias latipes. (a) Dorso-ventral view of Fish 4. Tumor protrudes from lateral aspect of head, posterior to left eye (arrows). (b) Lateral view of Fish 4 . Tumor extends from behind eye, over operculum, to base of pectoral fin (arrow heads). Scale bar $=0.5 \mathrm{~cm}$

Although Fish 2 had no grossly visible lesion, a large unencapsulated mass of round cells was found centered in 1 of the thymus glands. The tumor was similar in histologic appearance and distribution to tumors in the Fish 3 to 6 , with total effacement of normal thymic architecture and local invasion into adjacent structures of the head (Table 2). The tumor in Fish 2 differed, however, from those fish with gross lesions in that the thymus was the only lymphoid organ involved (kidney and spleen were negative) and by the absence of distant metastasis to the heart, peritoneal cavity, and major abdominal organs. The tumor was classified as a thymic lymphoma (Table 3).
Fish 1 differed from the other 5 medaka in that there was no thymic involvement. Fish 1 did, however, have massive renal interstitial infiltration similar to that found in the 4 fish with grossly visible tumors. The round cells in the kidney of Fish 1 were monomorphic, but differed from those in the other 5 fish by being slightly larger ( 5 to $7.5 \mu \mathrm{m}$ ), having larger, more irregular, vesicular nuclei, and having a much higher mitotic index (15 to $20 \mathrm{HPF}^{-1}$; Fig. 4). In addition to the primary renal involvement, there was massive infiltration of neoplastic round cells into the left eye, moderate infiltration of the spleen, small perivascular foci in the liver, small subcutaneous aggregates along the dorsal 


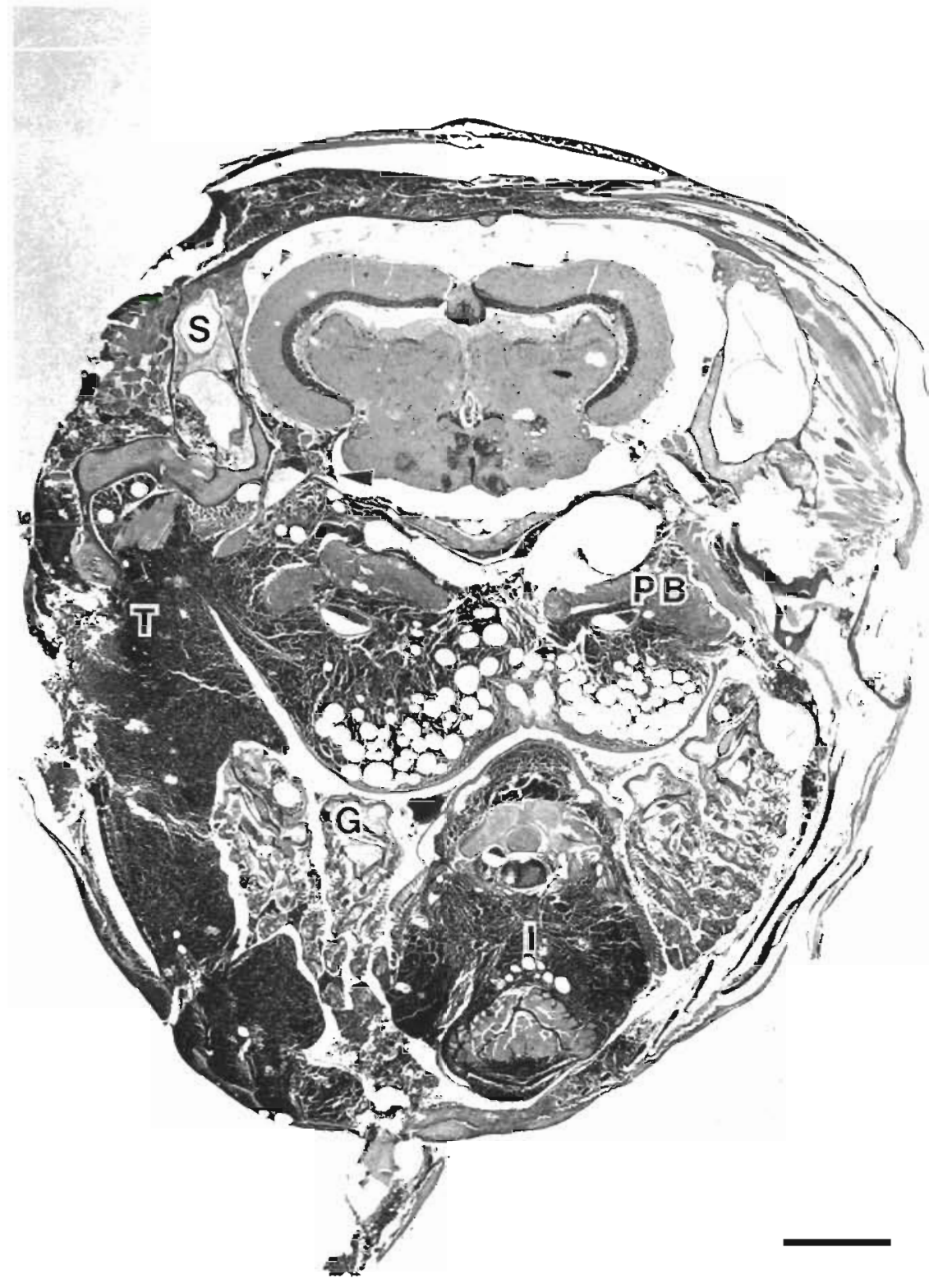

Fig. 2. Oryzias latipes. Cross section through head of Fish 4 at level of mesencephalon. Large mass of round cells, centered in the thymus ( $\mathrm{T}$ ), fills the opercular cavity and infiltrates into filaments of gill $(G)$, isthmus (I) separating 2 opercular cavities, oral submucosa, connective tissue surrounding the pseudobranch (PB), semicircular canals (S) of the inner ear, cranial nerves and meninx of the brain (arrow head). $\mathrm{H} \& \mathrm{E}$, scale bar $=$ $500 \mathrm{um}$

aspect of the fish, and small subendocardial infiltrates in the heart (Table 2). The tumor was classified as a renal lymphoma (Table 3)

Summarizing the lesions in all 6 fish, the most commonly affected organs $(5 / 6=5$ out of 6 fish) were the kidney, thymus, oral submucosa, thyroid gland, skeletal muscle, inner ear, eye, gill, pericardial sac, heart, and nervous system (Tables 2 and 3). Less commonly involved organs were the peritoneal cavity (4/6). liver $(4 / 6)$, spleen $(3 / 5)$, intestine $(2 / 6)$, and gonad $(2 / 6)$. The degree of infiltration was variable from fish to fish and between different organs, but tended to be most severe $(4+)$ in fish with disseminated lesions (Fish 3 to $6)$, in the thymus and those organs in close association with the thymus (oral submucosa, thyroid gland, skeletal muscle, and pericardial sac), and in the kidney. Organs with the mildest infiltrates ( 1 to $2+$ ) were the inner ear, liver, and intestine.

\section{Electron microscopic findings}

The round cells in Fish 4 and 6 were characterized ultrastructurally, by smoothly contoured cell membranes, lack of intercellular bridges, and having a minimal complement of cytoplasmic organelles (Fig. 5). Mitochondria, free ribosomes, and small amounts of rough endoplasmic reticulum were the only organelles that appeared with any regularity. Nuclei were pleomorphic with clumped chromatin and 1 or 2 prominent 
Table 2. Oryzias latipes. Metastatic lesions in nonlymphoid organs, tumor cell size (size, $4 \mathrm{~m}$ ), and mitotic index (MI = mitotic units/HPF). Organs listed in order of degree of neoplastic infiltrate and tumor infiltrate graded on scale of $1+$ to $4+(4+=$ massive involvement)

\begin{tabular}{|c|c|c|c|}
\hline Fish & Nonlymphoid organs with metastases & Size & MI \\
\hline 1 & Eye $(4+)$, liver $(1+)$, heart $(1+)$, subcutaneous tissue $(1+)$ & 7.5 & $15-20$ \\
\hline 2 & $\begin{array}{l}\text { Oral submucosa }(4+) \text {, thyroid }(4+) \text {, skeletal muscle }(2+) \text {, pericardial sac } \\
(2+) \text {, CNS }(2+) \text {, gill }(1+) \text {, inner ear }(1+) \text {, eye }(1+)\end{array}$ & 5 & $0-2$ \\
\hline 3 & $\begin{array}{l}\text { Oral submucosa }(4+) \text {, thyroid }(4+) \text {, skeletal muscle }(4+) \text {, pericardial sac } \\
(4+) \text {, ovary }(4+) \text {, CNS }(3+) \text {, heart }(3+) \text {, gill }(3+) \text {, eye }(3+) \text {, inner ear }(2+) \text {, } \\
\text { liver }(2+) \text {, intestine }(2+) \text {, peritoneal cavity }(2+)\end{array}$ & 5 & $0-1$ \\
\hline 4 & $\begin{array}{l}\text { Oral submucosa }(4+) \text {, thyroid }(4+) \text {, skeletal muscle }(4+) \text {, pericardial sac } \\
(4+) \text {, CNS }(3+) \text {, inner ear }(2+) \text {, gill }(2+) \text {, peritoneal cavity }(2+) \text {, eye }(1+) \text {, } \\
\text { liver }(1+) \text {, heart }(1+)\end{array}$ & $4-5$ & $0-2$ \\
\hline 5 & $\begin{array}{l}\text { Oral submucosa }(4+) \text {, thyroid }(4+) \text {, skeletal muscle }(4+) \text {, pericardial sac } \\
(4+) \text {, peritoneal cavity }(4+) \text {, inner ear }(3+) \text {, eye }(3+) \text {, ovary }(3+) \text {, heart }(3+) \text {, } \\
\text { CNS }(3+) \text {, gill }(2+) \text {, intestine }(2+) \text {, liver }(1+)\end{array}$ & $4-5$ & $0-1$ \\
\hline 6 & $\begin{array}{l}\text { Thyroid }(4+) \text {, skeletal muscle }(3+) \text {, inner ear }(2+) \text {, eye }(2+) \text {, gill }(2+) \text {, heart } \\
(2+) \text {, pericardial sac }(2+) \text {, oral submucosa }(1+) \text {, peritoneal cavity }(1+) \text {, CNS } \\
(1+)\end{array}$ & $4-6$ & $0-4$ \\
\hline
\end{tabular}

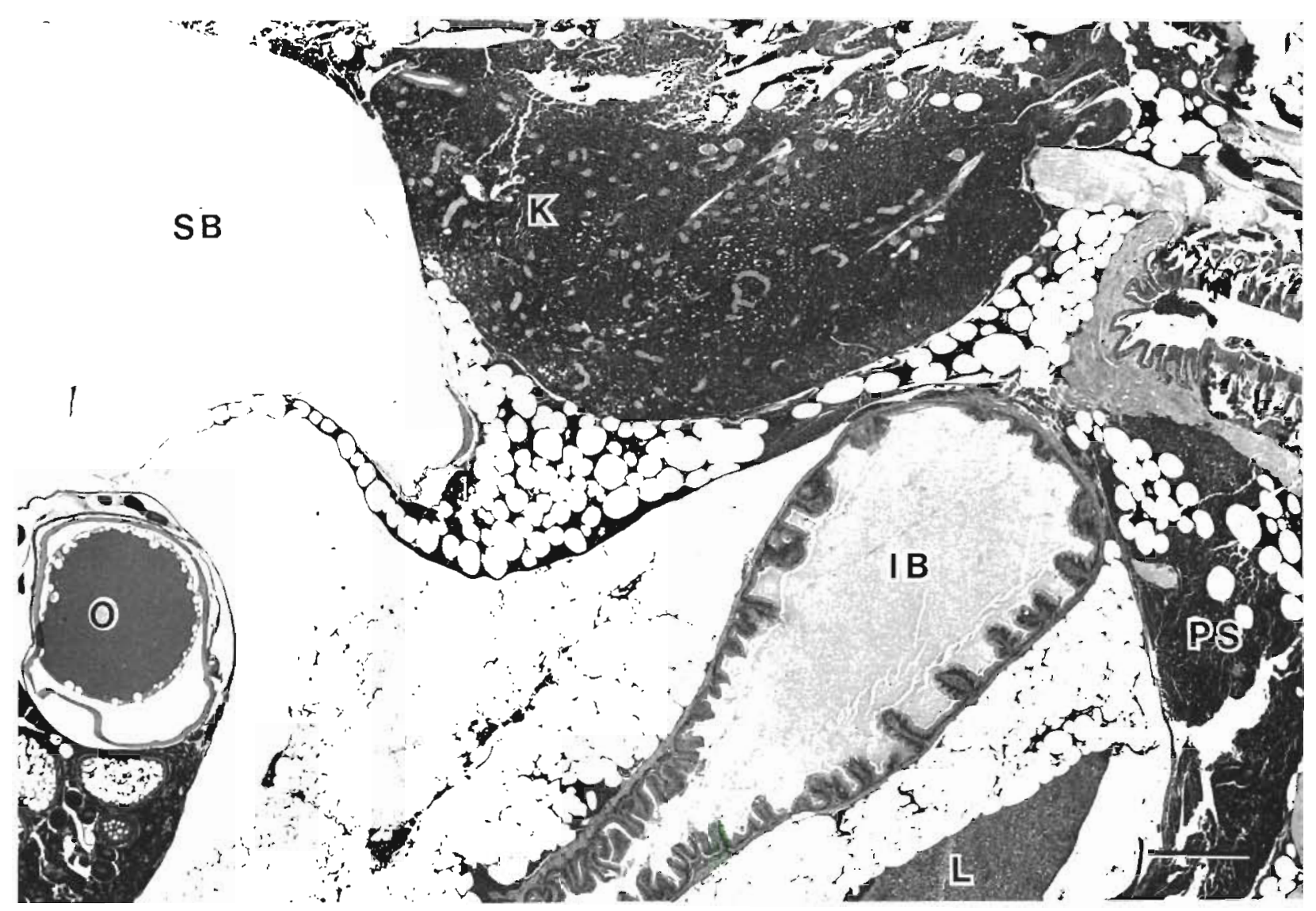

Fig. 3. Oryzias latipes. Longitudinal section through abdomen of Fish 3. Massive replacement of hematopoietic tissue in head kidney $(K)$ by diffuse sheets of round cells. Perirenal fat, pericardial sac (PS), and ovary (O) were similarly affected. Small aggregates of tumor cells also scattered throughout the abdominal fat. Swim bladder (SB), intestinal bulb (IB), and liver (L) not

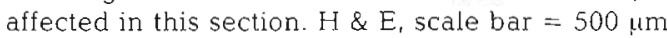


Table 3. Primary tumor location, histologic lymphoid organ involvement, and tumor classification. Degree of tumor involvement graded on a scale of (-) to $4+$ with (-) indicating absence of neoplastic lymphocytes and $4+$ indicative of massive infiltration. NE not examined (tissue lost during sectioning)

\begin{tabular}{|cccccc|}
\hline \multirow{2}{*}{ Fish } & Primary tumor location & \multicolumn{3}{c}{ Lymphoid organs involved } & Tumor classification \\
& & Kidney & Thymus & Spleen & \\
\hline 1 & Kidney & $4+$ & $(-)$ & $2+$ & Renal lymphoma \\
2 & Thymus & $(-)$ & $4+$ & $(-)$ & Thymic lymphoma \\
3 & Undetermined & $4+$ & $4+$ & $3+$ & Disseminated lymphoma \\
4 & Undetermined & $4+$ & $4+$ & $4-$ Disseminated lymphoma \\
5 & Undetermined & $4+$ & $4+$ & $4+$ & Disseminated lymphoma \\
6 & Undetermined & $4+$ & $4+$ & NE & Disseminated lymphoma \\
\hline
\end{tabular}

nucleoli. Large macrophages scattered throughout the tumors often had phagocytized suund celis.

\section{DISCUSSION}

The diagnosis of lymphoma in the Japanese medaka Oryzias latipes was based on the characteristic gross, light microscopic, and electron microscopic features of the neoplasm as described in both mammals and poikilotherms. Tumors occurred in sexually mature fish and were equally divided among males and females Lymphomas were manifested grossly, in the majority of fish, as large masses protruding from the head, but could also present as unilateral exophthalmos or with no gross lesions.

Lymphomas were classified as renal, thymic, or disseminated based on histologic distribution and extent of the neoplastic infiltrate. Identification of kidney or thymus as the primary site of tumor formation was made

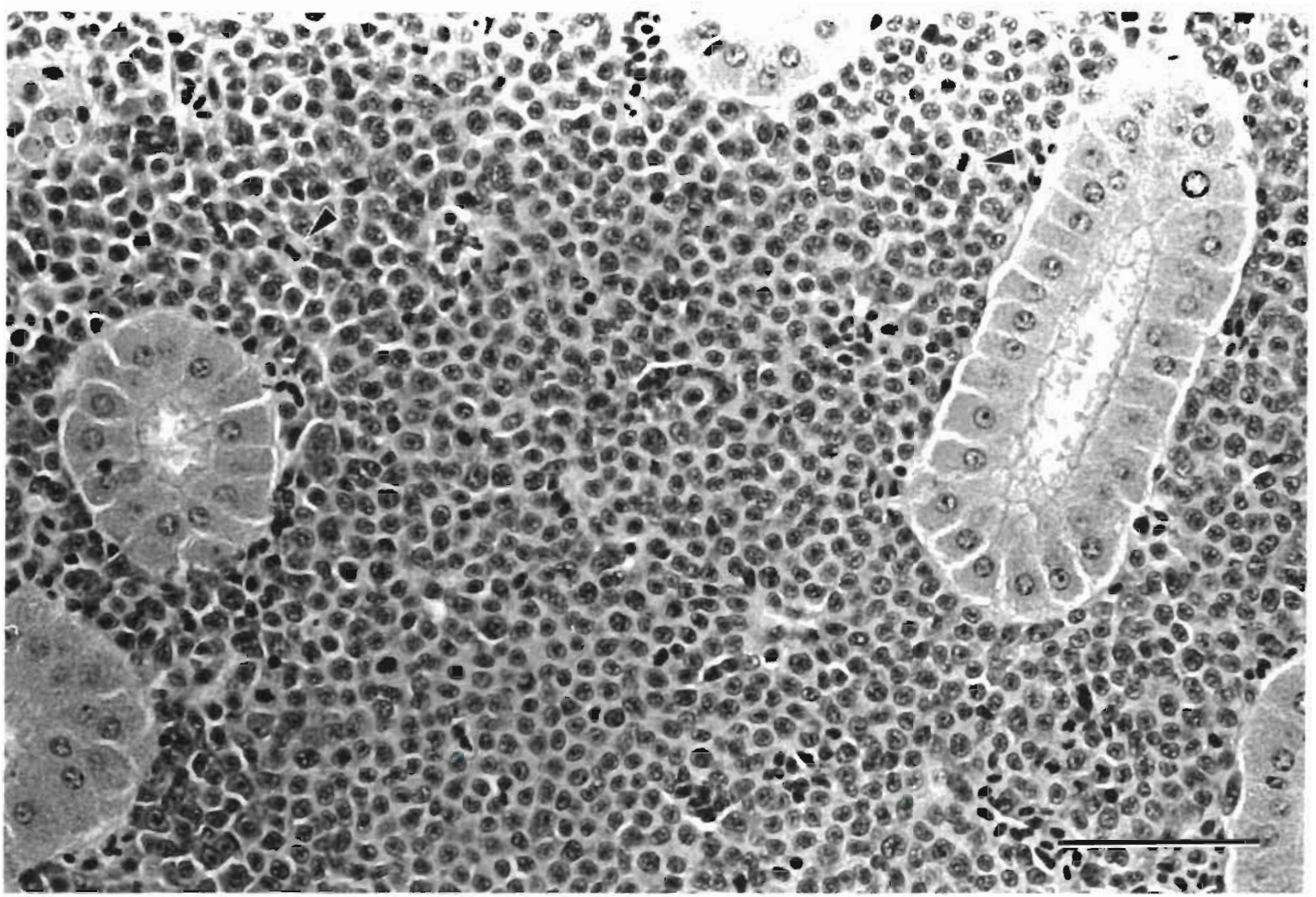

Fig. 4. Oryzias latipes. Kidney of Fish 1. Wide separation of renal tubules by monomorphic round cells. Note the numerous mitotic units (arrow heads). H \& E, scale bar $=50 \mu \mathrm{m}$ 


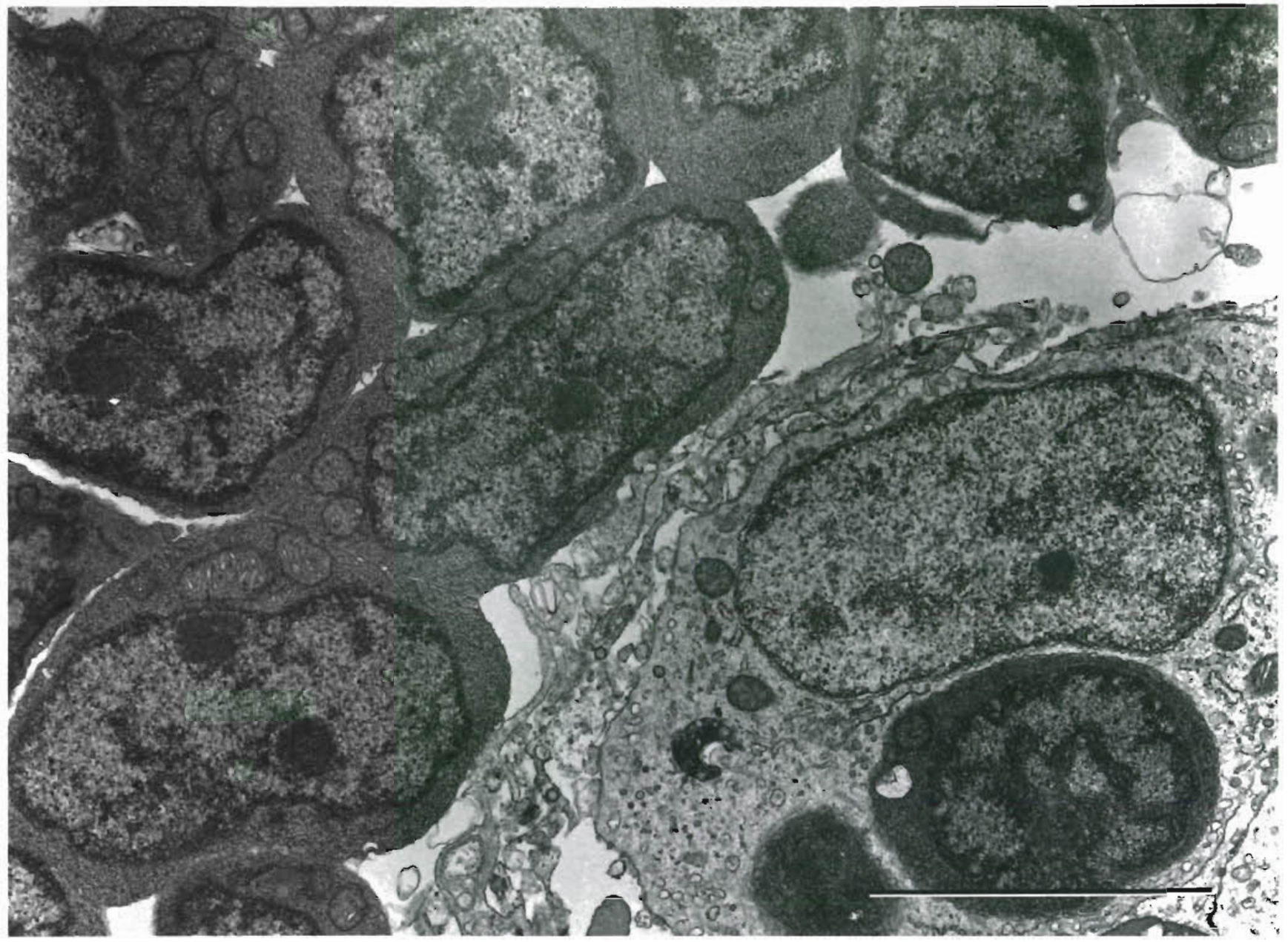

Fig, 5. Oryzias latipes. Neoplastic round cells in kidney of Fish 4. Note scant cytoplasm with numerous free ribosomes, scattered large mitochondria, and a few profiles of rough endoplasmic reticulum. Nuclei were irregular with clumped chromatin and prominent nucleoli. Note the large macrophage with phagocytized tumor cell. Uranyl acetate and lead citrate, scale bar $=4 \mu \mathrm{m}$

when other lymphoid or hematopoietic organs could reasonably be eliminated as potential sites of tumor origination. In the case of the renal lymphoma in Fish 1 , the thymus was completely uninvolved and the spleen only mildly infiltrated. Localization of neoplastic lymphocytes to the kidney of Fish 1, with lack of thymic involvement, is comparable to lymphomas reported in the grayling Thymallus thymallus (Hoffman et al. 1988), Atlantic salmon Salmo salar (Haddow \& Blake 1933), and conger eel Conger conger (Williams 1931). In the case of the thymic lymphoma in Fish 2, neither the kidney nor spleen were infiltrated. The diagnosis of disseminated lymphoma was made when more than 1 lymphoid organ was involved and when there was widespread metastasis of malignant lymphocytes. Although the primary site of tumor formation could not be definitively identified in medaka with disseminated lymphoma, the gross appearance of the tumors arising from the thymus, unilateral involvement of the thymus, and massive infiltration of organs adjacent to the thymus were all suggestive that the thymus may have been the primary site of tumor formation. The thymic and disseminated lymphomas in medaka closely resemble reports of thymic lymphoma in the rainbow trout (Dunbar 1969, Hermann 1969, Harshbarger 1980, Bernstein 1984, Warr et al. 1984) and brook trout (Dunbar 1969).

Metastatic lesions were found in all 6 fish and occurred via both direct extension and vascular invasion. Metastasis via direct extension was usually associated with expansive thymic masses, while vascular invasion was most evident when the kidney was infiltrated. Medaka with disseminated lymphoma illustrated both types of metastatic lesions. The disseminated tumors appear to start as unilateral thymic lesions that grow pragressively larger and spread via direct extension into adjacent structures in the head (oral submucosa, thyroid gland, skeletal muscle, cranial nerves, brain, gills, inner ears, and eyes). Invading lymphocytes simultaneously 
extend caudally to incorporate the pericardial sac, kidney, perirenal fat, and peritoneal cavity. Further dissemination occurs later when the tumor cells invade blood vessels in the kidney (and probably other organs) and the fish becomes leukemic. Neoplastic lymphocytes subsequently spread via the vasculature into the endocardium of the heart, lamina propria of the intestine, perivascular locations in the liver, white pulp of the spleen, and interstitium of the gonad. In Fish 1, vascular metastasis was also assumed to have resulted in the ocular and subcutaneous lesions.

The etiology of lymphomas in Japanese medaka has not been determined. The tumors appeared spontaneously in control fish that were not deliberately exposed to any known carcinogens (broodstock and rearing facility separated from carcinogen exposure building by $4 \mathrm{~km}$ ). And although retroviruses are well established as the cause of lymphoma in many species of domestic mammals (Moulton \& Dungworth 1978) and are suspected of causing cutaneous lymphomas in pike and muskellunge (Mulcahy \& O'Leary 1970, Papas et al. 1976, Sonstegard 1976, Papas et al. 1977, Yamamoto et al. 1983), no viral particles were seen in any of the medaka tumor tissue examined via TEM. Still, the quantity of tumor tissue examined was limited and a viral etiology remains a possibility.

The significance of lymphomas as a threat to our normal broodstock population of Japanese medaka is minimal. Although the tumors are malignant and fatal when disseminated, they occur only sporadically and the current incidence of ca $0.2 \%$ (6 fish with lymphoma per 3000 total adults in the colony), over a 6 mo period, is extremely low. The primary benefit is that we are aware of the occurrence of lymphomas in our colony as part of the normal background incidence of tumors. This knowledge will help us to avoid automatically (and erroneously) attributing any lymphomas we detect in the future to xenobiotic exposures we may have performed (unless the incidence of lymphomas is significantly elevated above the background level established for our colony). The point is clearly illustrated by the report of 2 cases of lymphoma in channel. catfish subjected to long-term exposure with $\mathrm{N}$-methyl$N^{\prime}$-nitrosoguanidine (Chen et al. 1985), because during that same year, Bowser et al. (1985) subsequently reported on a spontaneous case of lymphoma in the channel catfish.

In summary, lymphoma does occur sporadically in Japanese medaka as a spontaneous neopldsm. The tumor apparently originates in either the kidney or thymus, but is most often manifested grossly as a visible lesion on the head after the tumor had disseminated widely. Metastasis occurs via both direct extension and vascular invasion, and the etiology is unknown at this time.
Acknowledgements. We thank Swee Teh and John Schmidt for technical assistance. This study was supported in part by Public Health Service Grant CA45131 from the National Cancer Institute.

\section{LITERATURE CITED}

Bernstein, J. W. (1984). Leukaemic lymphosarcoma in a hatchery-reared rainbow trout, Salmo gairdneri Richardson. J. Fish Dis. $7 \cdot 83-86$

Bowser, P. R., McCoy, C. P., Macivillan, J. R. (1985). A lymphoproliferative disorder in a channel catfish, Ictalurus punctatus (Rafinesque). J. Fish Dis. 8: 465-469

Chen, H. H., Brittelli, M. R., Muska, C. F. (1985). Two cases of lymphosarcoma in channel catfish exposed to $\mathrm{N}$-nethyl$\mathrm{N}^{\prime}$-nitro-N-nitrosoguanidine. J. natl Can. Inst. 74: 933-939

Dawe, C. J. (1969). Neoplasms of blood cell origin in poikilothermic animals - a review. In: Lingeman, $C$., Garner, G. (eds.) Comparative morphology of hemopoietic neoplasms. Natl Can. Inst. Monogr No. 32: 7-28

Dunbar, C. E. (1969). Lymphosarcoma of possible thymic origin in salmonid fishes. Natl Can. Inst. Monogr. No. 31: $167-171$

Haddow, A., Blake, I. (1933). Neoplasms in Fish: a report of 6 cases with a summary of the literature. J. Pathol Bacteriol. 36: $41-47$

Harshbarger, J. C. (1980). Acitivities report. Registry of tumors in lower animals: 1979 supplement. Smithsonian Institute, Washington, D.C

Harshbarger, J. C., Dawe, C. J. (1973). Hematopoietic neoplasms in invertebrate and poikilothermic vertebrate animals. In: Dutcher, R. M., Bianchi, L. C. (eds.) Unifying concepts of leukemia. Bibliotheca haematologica 39. Karger, Basel, p. 1-25

Herman, R. L. (1969). Lymphosarcoma of the thymus of salmonids. In: Dutcher, R. M. (ed.) Comparative leukemia research. Bibliotheca haematologica 36. Karger, Basel, p. 646

Hinton, D. E. (1985). Japanese medaka liver tumor model: review of literature and new findings. In: Jolley, R. L., Bull, R. J., Davis, W. P., Katz, S., Roberts, M. H., Jacobs, V. A. (eds.) Water chlorination chemistry, environmental impact and health effects, Vol. 5. Lewis Publishers, Inc., Chelsea, p. $439-450$

Hoffmann, R. W., Fischer-Scherl, T., Pfeil-Putzien, C. (1988). Lymphosarcoma in a wild grayling, Thymallus thymallus L.: a case report. J. Fish Dis, 11: 267-270

Ljungberg, $O$. (1976). Epizootiological and experimental studies of skin tumours in northern pike (Esox lucius L.) in the Baltic sea. In: Hornburger, F. (ed.) Progress in experimental tumor research 20. Karger, Basel, p. 156-165

Mawdesley-Thomas, L. E. (1975). Neoplasia in fish. In: Ribelin, W. E., Migaki, G. (eds.) The pahtology of fishes. The University of Wisconsin Press, Madison, p. 805-870

Mouiton, J. E., Dungworth, D. L. (1978). Tumors of the lymphoid and hemopoietic tissues. In: Moulton, J. E. (ed.) Tumors in domestic animals. University of California Press, Berkeley, p. 150-204

Mulcahy, M. F. (1963). Lymphosarcoma in the pike, Esox lucius L. (Pisces; Esocidae) in Ireland. Proc. R. Ir. Acad., Sect. B 63: 103-129

Mulcahy, M. F. (1976). Epizootiological studies of lymphomas in northern pike in Ireland. In: Homburger, F. (ed.) Progress in experimental tumor research 20. Karger, Basel, p. $129-140$ 
Mulcahy, M. F., O'Leary A. (1970). Cell-free transmission of lymphosarcoma in the northern pike Esox lucius L. (Pisces; Esocidae). Experientia 26: 891

Papas, T S., Dahlberg, J. E., Sonstegard, R. A. (1976). Type C virus in lymphosarcoma in northern pike (Esox lucius). Nature, Lond. 261: 506-508

Papas, T S., Pry, T W., Schafer, M. P., Sonstegard, R. A. (1977). Presence of DNA polymerase in lymphosarcoma in northern pike (Esox lucius). Cancer Res. 37: 3214-3217

Roald, S. O., Hastein, T (1979). Lymphosarcoma in an Atlantic salmon Salmo salar L. J. Fish Dis. 2: 249-251

Schlumberger, H. G., Lucke, B. (1948). Tumors of fishes, amphibians, and reptiles., Cancer Res. 8: 657-760

Smith, C. E. (1971). An undifferentiated hematopoietic neoplasm with histologic manifestations of leukemia in a cutthroat trout (Salmo clarki). J. Fish. Res. Bd Can. 28: $112-113$

Sonstegard, R. (1975). Lymphosarcoma in Muskellunge (Esox masquinongy). In: Ribelin, W. E., Migaki, G. (eds.) The pathology of fishes. The University of Wisconsin Press, Madison. p. 907-924

Responsible Subject Editor: Professor N. Peters, Hamburg, F.R. Germany
Sonstegard, R. A. (1976). Studies of the etiology and epizootiology of lymphosarcoma in Esox (Esox lucius L. and Esox masquinongy). In: Homburger, F. (ed.), Progress in experimental tumor research 20. Karger, Basel, p. $141-155$

Thompson, J.S. (1982). An epizootic of lymphoma in northern pike, Esox lucius L., from the Aland Islands of Finland. J. Fish Dis. 5: 1-11

Warr, G. W., Griffin, B. R., Anderson, D. P., McAllister, P. E., Lidgerding, B., Smith, C. E. (1984). A lymphosarcoma of thymic origin in the rainbow trout, Salmo gairdneri Richardson. J. Fish Dis. 7: 73-82

Wellings, S. R. (1969). Neoplasia and primitive vertebrate phylogeny: echinoderms, prevertebrates, and fishes - a review. Natl Can. Inst. Monogr. No. 31. 59-128

Williams, G. (1931). On various fish tumors. Proc. Trans. Lpool biol. Soc. 45: 98-109

Yamamoto, T., Kelly, R. K., Nielsen, O. (1983). Epidermal hyperplasias of Northern pike (Esox lucius) associated with herpesvirus and C-type particles. Arch. Virol. 79: $255-272$

Manuscript first received: June 26, 1989

Revised version accepted: August 14, 1989 